\title{
Peran Humas XI Axiata Melalui Mobile Laut Nusantara dalam Membangun Citra Perusahaan bagi Nelayan
}

\author{
Alvian Jelang Ramadhan \\ Program Pascasarjana Ilmu Komunikasi, Institut Komunikasi dan Bisnis LSPR \\ E-mail: alvianjelang681@gmail.com
}

DOI: https://doi.org/10.21107/ilkom.v15i1.8807

\begin{abstract}
ABSTRAK
Penelitian untuk mengetahui peran humas XL Axiata melalui aplikasi mobile Laut Nusantara untuk membangun citra perusahaan bagi nelayan. Penelitian ini menggunakan metode penelitian Kualitatif studi kasus. Hasil Penelitian ini adalah kegiatan Aplikasi Laut Nusantara berjalan dengan baik dan lancar. Humas XL telah berhasil menyelenggarakan kegiatan Aplikasi Laut Nusantara karena aplikasi tersebut juga dapat diterima dengan baik oleh para nelayan khususnya nelayan jukung. Aplikasi Laut Nusantara merupakan aplikasi pertama karya anak bangsa yang dibuat untuk masyarakat Indonesia khususnya para nelayan, aplikasi ini mempunyai kelebihan yang dapat dimanfaatkan oleh para nelayan yaitu: sebaran ikan dilautan, perkiraan cuaca, melaporkan hasil tangkapan, harga ikan di pelabuhan, perkiraan bahan bakar yang dibutuhkan pada saat melaut. Penyelenggaraan kegiatan Aplikasi Laut Nusantara dapat membangun citra positif perusahaan bagi para nelayan. Dengan pelaksanaan yang sangat baik dan memenuhi segala syarat serta kriteria dari penyelenggaraan kegiatan Aplikasi Laut Nusantara menghasilkan citra yang positif di benak para nelayan yang hadir dalam kegiatan tersebut. Penelitian ini memiliki saran yaitu aplikasi Laut nusantara hanya bisa digunakan di android versi kitkat ke atas belum bisa di iOS atau iphone, sebaiknya aplikasi Laut Nusantara juga bisa digunakan di versi iOS atau iphone meskipun nelayan jarang yang menggunakan iphone tetapi hal ini dinilai sangat penting karena para nelayan tidak hanya menggunakan android.
\end{abstract}

Kata Kunci: corporate communication, aplikasi laut nusantara, citra, nelayan

\begin{abstract}
Research to determine the role of XL Axiata public relations through the Laut Nusantara mobile application to improve the company image for fishermen. This research uses a case study qualitative research method. The result of this research is that the activities of the Nusantara Laut Application run well and smoothly. XL Public Relations has succeeded in holding the Nusantara Laut Application activity because the application has also been well received by fishermen, especially Jukung as fishermen. The Laut Nusantara application is the first application created by the nation's children made for the people of Indonesia, especially fishermen, this application has advantages that can be used by fishermen, namely: distribution of fish in the sea, weather forecasts, reporting catches, fish prices in ports, estimated fuel consumption. needed at sea. The implementation of Nusantara Laut Application activities can build a positive company image for fishermen. With a very good implementation and fulfilling all the requirements and criteria for the implementation of Nusantara Laut Application activities, it produces a positive image in the minds of
\end{abstract}

\section{Cite this as :}

Ramadhan, Alvian Jelang. (2021). Peran Humas Xl Axiata Melalui Aplikasi Mobile Laut Nusantara dalam Membangun Citra Perushaan bag Nelayan. Jurnal Komunikasi, 15(1), 1-16. doi: https://doi.org/10.21107/ilkom.v15i1.8807

Article History :

Received Oktoberr, $10^{\text {th }} 2020$, Acepted Desember, $12^{\text {th }} 2020$ 
the fishermen who attend the activity. This research has a suggestion that the Nusantara Laut application can only be used on the Android KitKat version and above cannot be used on iOS or iPhone, it is better if the Laut Nusantara application can also be used on the iOS or iPhone version although fishermen rarely use iPhone this is considered very important because fishermen don't just use android.

Keywords: corporate communication, aplikasi laut nusantara, image, fisherman

\section{PENDAHULUAN}

Sebagai pelayan publik, tentu saja setiap operator telekomunikasi selalu bersentuhan langsung dangan para pelanggannya. Oleh karena itu, XL Axiata harus menjaga kepuasan pelanggan dengan memberikan pelayanan yang terbaik, sehingga benar-benar bisa dirasakan oleh setiap pelanggannya. Selain itu, XL Axiata harus memiliki fasilitas jaringan yang baik, sistem operator yang memadai untuk menunjang kenyamanan bagi setiap pelanggannya.

Berdasarkan data Embracing Digitization For Our Future (2018) PT XL AXIATA, Tbk sebagai salah satu perusahaan operator telekomunikasi seluler di asia, telah beroperasi di Indonesia sejak tahun 1996. Saat ini XL menjadi milik masyarakat mayoritas asia dari Axiata Group Berhad (Axiata Group) melalui Axiata Investments (Indonesia) dahulu adalah Indocel Holding Sdn. Bhd $(66,5 \%)$ dan sisanya adalah publik $(33,45 \%)$. XL berada dalam Axiata Group bersama-sama dengan Aktel (Bangladesh), Hello (Cambodja), Idea (India), MTCE (Iran), Celcom (Malaysia), Multinet (Pakistan), M1 (Singapore), Samart (Thailand), dan Dialog (Srilanka).

Pada tahun 2018 merupakan periode terberat bagi industri telekomunikasi Indonesia karena para industri telekomunikasi harus menghadapi kebijakan pemerintah tentang penerapan registrasi kartu SIM prabayar maupun pascabayar menggunakan nomor Kartu Keluarga (KK). Namun XL mampu mengatasi kebijakan itu dengan baik sehingga para konsumen tetap setia memakai kartu XL (Pratomo, 2018). Berikut data Pencapaian kinerja XL tahun 2018 (Embracing Digitization For Our Future):

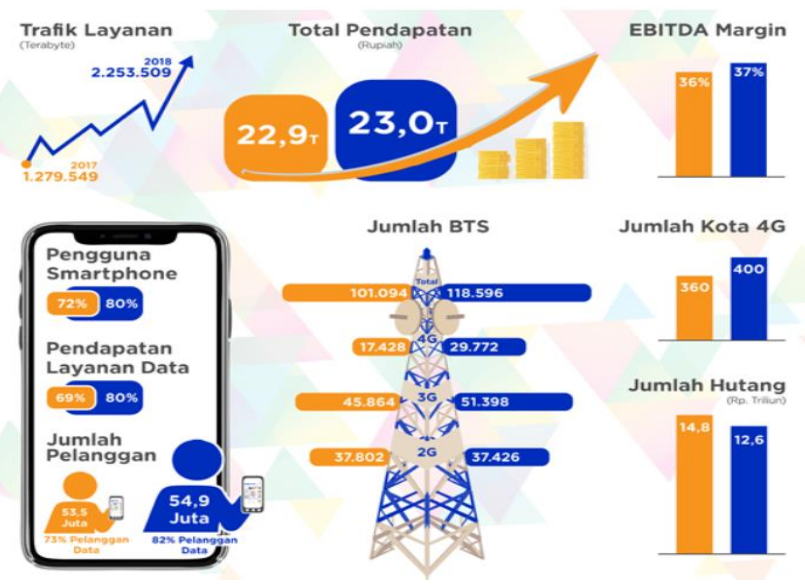

Gambar 1. Pencapaian Kinerja XL Tahun 2018 (Embracing Digitization For Our Future,2018)

Dilihat dari data Embracing Digitization For Our Future (2018 di atas menutup tahun 2018 dengan pencapaian kinerja positif, melampaui pencapaian secara rata-rata industri telekomunikasi Indonesia. XL Axiata mencatat pertumbuhan pendapatan sebesar 0,4\% lebih tinggi dari pencapaian tahun lalu. Pertumbuhan XL Axiata tersebut, terutama didorong oleh pendapatan dari layanan data yang meningkat $13 \%$ dibandingkan periode yang sama tahun sebelumnya (YoY). Peningkatan ini memperbesar kontribusi pendapatan layanan data pada total pendapatan perusahaan menjadi $80 \%$ per akhir 2018, meningkat dari $69 \%$ di tahun sebelumnya. XL Axiata berhasil mengungguli para kompetitor dan memperkuat posisi sebagai operator nomor 2 di Indonesia, hasil ini tidak terlepas dari konsistensinya dalam menerapkan strategi menempatkan layanan data sebagai fokus utama pengembangan bisnis

Pencapaian yang telah diraih oleh PT XL Axiata tidak lepas dari Kerjasama tim antar divisi yang sudah berjalan dengan baik. Ada salah satu divisi yang berperan penting dalam mengkoordinasikan anatar divisi satu 
dengan yang lainnya yaitu corporate communication dimana divisi ini memanfaatkan perkembangan teknologi melalui media digital. Perkembangan teknologi melalui media digital menuntut praktisi PR mengembangkan model komunikasi korporat dengan pemanfaatan media sosial/ media digital melalui, model nilai tambah (value added model) yang mencerminkan proses komunikasi perusahaan di media sosial (Ruliana, Lestari, \& Andrini, 2019)

Humas XL telah mengadopsi revolusi PR 4.0 melalui kegiatan CSR, mereka terus berinovasi dengan terobosan yang salah satunya teknologi berbasis internet. Dengan mengadopsi teknologi berbasis internet yaitu media digital humas XL meluncurkan program CSR Aplikasi Laut Nusantara yang ditujukan bagi para nelayan di seluruh Indonesia. Peluncuran program tersebut berbentuk sebuah aplikasi mobile atau alat bantu untuk mencari ikan bagi nelayan.

Peluncuran program CSR Laut Nusantara yang berbentuk aplikasi mobile yang ditujukan bagi nelayan aplikasi itu bernama Laut Nusantara. Aplikasi mobile Laut Nusantara adalah sebuah alat bantu untuk mencari ikan bagi nelayan agar pekerjaan nelayan dapat terbantu melalui aplikasi Laut Nusantara. Aplikasi mobile ini juga merupakan peluncuran yang kedua bagi XL yang sebelumnya bernama mFish, perbedaannya dengan yang pertama adalah aplikasi mobile Laut Nnusantara bekerja sama dengan Balai Riset dan Observasi Laut (BROL) yang dimana memiliki data kelautan yang sangat lengkap dan berguna untuk pengembangan di bidang kelautan ( $\mathrm{T}$. Wijahjono, 2019).

Menurut Prastowo dan Huda (2011, p. 101) bahwa "Responsibility of organization for the impacts of its decisions and activities on society and the environment, through transparent and ethical behavior that contributes to sustainable development, including health and the welfare of society; takes into account the expectations of stakeholders; is in compliance with applicable law and consistent with international norms of behavior; and is integrated throughout the organization and practiced in its relationship". "Tanggung jawab organisasi atas dampak keputusan dan kegiatannya terhadap masyarakat dan lingkungan, melalui perilaku yang transparan dan etis yang berkontribusi pada pembangunan berkelanjutan, termasuk kesehatan dan kesejahteraan masyarakat; memperhitungkan harapan pemangku kepentingan; mematuhi hukum yang berlaku dan konsisten dengan norma perilaku internasional; dan terintegrasi di seluruh organisasi dan dipraktikkan dalam hubungannya".

Johnson dan Johnson dalam Hadi (2011: 46) mendefinisikan Corporate Social Responsibility is about how companies manage the business processes to produce an overall positive impact on society. Definisi tersebut pada dasarnya berangkat dari filosofi bagaimana cara mengelola perusahaan, baik sebagian maupun secara keseluruhan memiliki dampak yang positif bagi perusahaan dan lingkungan. Oleh karena itu, perusahaan harus mampu mengelola bisnis operasinya dengan menghasilkan produk yang berorientasi secara positif terhadap masyarakat dan lingkungan.

Dapat peneliti pahami bahwa CSR merupakan sebuah kegiatan tanggung jawab sosial perusahaan dalam memanfaatkan sumber daya perusahaan untuk meminimalisir dampak negatif dan memaksimalkan dampak positif masyarakat yang mencakup aspek ekonomi, sosial, lingkungan, pendidikan, serta kesejahteraan masyarakat, yang secara tidak langsung nantinya akan membentuk opini yang positif bagi masyarakat kepada perusahaan.

Program XL Laut Nusantara yang dilaksanakan oleh humas XL, yang dilakukan sejak September tahun 2018. Program tersebut merupakan program yang pertama kali dilakukan oleh operator di Indonesia sehingga, diharapkan program Laut Nusantara 
dapat membangun citra yang positif bagi PT XL Axiata. Program Laut Nusantara juga secara tidak langsung mengajarkan atau memperkenalkan dunia digital kepada para nelayan bagaimana cara menggunakan internet.

Perkembangan aplikasi mobile (app istilah singkatnya) telah berkembang populer sejak munculnya iPhone pertama tahun 2007 dan juga Android. Aplikasi mobile native menawarkan berbagai fitur seperti homescreen icon, offline availability, push notification, geolocation, dan lainnya. Pada dasarnya, Progressive Web Application (PWA) adalah sebuah website yang dibangun menggunakan teknologi web modern, namun dapat berlaku seperti sebuah mobile app (Santoso, 2019).

Aplikasi Mobile adalah perangkat lunak yang berjalan pada perangkat mobile seperti smartphone atau tablet PC. Aplikasi Mobile juga dikenal sebagai aplikasi yang dapat diunduh dan memiliki fungsi tertentu sehingga menambah fungsionalitas dari perangkat mobile itu sendiri. Untuk mendapatkan mobile application yang diinginkan, user dapat mengunduhnya melalui situs tertentu sesuai dengan sistem operasi yang dimiliki. Google Play dan iTunes merupakan beberapa contoh dari situs yang menyediakan beragam aplikasi bagi pengguna Android dan iOS untuk mengunduh aplikasi yang diinginkan. (Mobile Marketing Association, 2015). Aplikasi mobile adalah sebuah aplikasi yang dirancang atau sebuah perangkat lunak yang dibuat untuk melayani kebutuhan dari beberapa aktivitas yang terdiri dari beberapa akses keberagam informasi yang relevan dengan aplikasi. Aplikasi mobile juga merupakan alat bantu yang dibuat untuk tujuan tertentu sehingga aplikasi mobile juga dapat dikatakan sebuah alat yang dapat mempermudah pekerjaan manusia.

Aplikasi mobile Laut Nsantara yang dilaksanakan oleh XL Axiata merupakan program yang sangat baik bukan hanya programnya saja tetapi juga memiliki aplikasi yang sangat baik, sehingga kegiatan tersebut diharapkan dapat menimbulkan citra yang positif dari masyarakat khususnya nelayan untuk menggunakan aplikasi hal tersebut. Namun bukan hanya citra positif saja yang muncul diharapkan juga dapat meningkatkan kepercayaan masyarakat kepada PT XL Axiata.

Program CSR Laut Nusantara merupakan sebuah bentuk komitmen XL kepada seluruh masyarakat Indonesia khususnya keapada pemerintah, hal ini merupakan sebuah tanggung jawab perusahaan yang harus dilaksanakan, melalui program CSR ini humas Xl berharap dapat meningkatkan citra perusahaanya bagi para nelayan. Menurut Ruslan (2013, p. 75) "Citra merupakan tujuan utama, dan sekaligus merupakan reputasi dan prestasi yang hendak dicapai bagi dunia public relations". Menurut Khadijah (2019), Pembentukan citra perusahaan tidak dapat dilakukan dalam waktu singkat, tetapi melalui proses yang panjang, dan tidak dapat dipoles. Citra yang tercipta tersebut sebaiknya merupakan kesan sebenarnya yang didasarkan kepada pengalaman dan pengetahuan serta pengertian terhadap kenyataan.

Peneliti memahami citra merupakan sebuah kesan seseorang terhadap sebuah objek yang akan mempersepsikan dan menilainya sebagai keyakinan di dalam dirinya. Bila dikaitkan dengan penelitian ini, secara tidak langsung humas XL telah membangun citra untuk perusahaannya melalui program CSR Laut Nusantara. Dengan demikian, masyarakat khususnya para nelayan akan menimbulkan persepsi dalam diri mereka yang positif mengenai citra perusahan XL dimana XL sudah mencoba membantu pemerintah dalam menyejahterakan para nelayan melalui programnya. Selama berjalan waktu dapat membangun citra perusahaan dengan pertumbuhan penggunaan alat bantu mencari ikan aplikasi Laut Nusantara dan operator XL Axiata. Rumusan permasalahan penelitian ini adalah bagaimana Peran Humas XL Axiata melalui Aplikasi Mobile Laut Nusantara dalam Membangun Citra Perusahaan Bagi 
Nelayan?. Adapun Tujuan penelitian ini adalah untuk mengetahui peran humas XL Axiata melalui program CSR dalam bentuk aplikasi mobile Laut Nusantara untuk membangun citra perusahaan bagi nelayan.

\section{Humas}

Menurut Cutlip, Center, dan Brown yang dikutip dalam Gassing dan Suryanto (2016, p.8) menyatakan bahwa "PR sebagai the planed effort to influence opinion through dan responsible performance, based on mutually satisfactory two-way communications". (usaha terencana untuk mempengaruhi pandangan melaului karakter yang baik serta tindakan yang bertanggung jawab, didasarkan atas komunikasi dua arah yang saling memuaskan).

Lalu Gassing dan Suryanto (2016, p. 15) PR merupakan fungsi manajemen artinya, PR bertugas membantu operasional manajemen organisai. Misalnya ketika menetapkan tujuan dan menerjemahkan berbagai kebijakan kepada publik serta menyesuaikan diri terhadap lingkungan yang selalu berubah. PR harus rutin memberikan saran dan solusi kepada manajemen, memiliki program kegiatan yang terencana dan mengarahkan dirinya untuk mencapai tujuan organisasi.

PR terkait erat dengan komunikasi. Public relations officer bertanggung jawab mengkomunikasikan berbagai kebijakan dan tindakan perusahaan kepada public, baik internal maupun eksternal. PR juga berkewajiban memberikan perhatian terhadap sikap, aspirasi dan perasaan khalayak untuk disalurkan dan disampaikan kepada pihak manajemen. Oleh sebab itu, PR harus menjadi mediator. Komunikasi yang dibangun sifatnya harus dua arah. Tujuannya harus menciptakan saluran informasi sehingga tidak ada aspirasi atau harapan dari dua belah pihak yang terhambat.

Hal yang dilakukan humas untuk mencapai tujuan yaitu citra positif yang saling pengertian antara publik dan organisasi.
Maka, banyak kegiatan public relations yang tersebar, bukan secara geografis tetapi secara demografis (RM \& Moertijoso, 2015).

Menurut Ardianto (dalam Alvin, 2020) public relations sebagai usaha terus menerus secara sadar untuk mempengaruhi publik melalui komunikasi, agar timbul rasa hormat terhadap individu maupun organisasi supaya dapat bertahan dalam menghadapi cobaan dan tantangan. Dari definisi di atas dapat peneliti pahami bahwa humas adalah fungsi manajemen yang terencana untuk mempengaruhi pandangan melalui karakter yang baik serta tindakan yang bertanggung jawab, didasarkan atas komunikasi dua arah yang saling menguntungkan atau memuaskan. Mencapai citra positif perusahaan harus mempunyai hubungan yang baik dengan para stakeholder. Hubungan itu dapat dibangun melaluin kegiatan-kegiatan public relations yang tersebar secara demografis. PR juga dapat mempengaruhi publikya melalui komunikasi agar publik mempunyai rasa hormat kepada perusahaan sebagai stakeholder yang memberikan bantuan kepada mastarakat. Humas XL Axiata sebagai interpreter atau sebagai mediator yang mampu menerjemahkan kebijakan dan program CSR Laut Nusantara kepada publik eksternal untuk menciptakan citra positif bagi perusahaan.

\section{Aplikasi Laut Nusantara}

Menurut Turban (2012, p. 277) mobile application juga biasa disebut dengan mobile apps, yaitu istilah yang digunakan untuk mendeskripsikan aplikasi internet yang berjalan pada smartphone piranti mobile lainnya. Aplikasi mobile biasanya membantu para penggunannya untuk terkoneksi dengan layanan internet yang biasa diakses pada PC atau mempermudah mereka untuk menggunakan aplikasi internet pada piranti yang biasa dibawa." Menurut Kriyantono (2012, p. 60) "Memudahkan hubungan dan berbagi antara perusahaan, prospek kerja, dan pelanggan; memudahkan hubungan media biaya murah dan cepat; memudahkan mendapat informasi beragam; memudahkan 
diskusi public dan memperoleh opini publik; sarana promosi dan pencitraan korporat; dan beradaptasi dengan kebutuhan publik."

Aplikasi Laut Nusantara merupakan peluncuran CSR aplikasi mobile kedua yang diluncurkan oleh XL. Aplikasi ini merupakan bentuk penyempurnaan dari aplikasi sebelumnya yang bernama mFish, perbedaan dari aplikasi sebelumnya adalah aplikasi Laut Nusantara sekarang telah memeiliki banyak keunggulan yang diantaranya memiliki fitur live chat, memiliki update cuaca dan titik-titik ikan berkumpul yang di update setiap minggunya oleh Balai Riset dan Observasi Laut (BROL), selanjutnya aplikasi Laut Nusantara juga memiliki perkiraan Bahan Bakar Minyak (BBM) yang dibutuhkan saat melaut.

Aplikasi terdiri dari program yang dirancang untuk memudahkan para penggunanya agar lebih produktif dan dapat membantu tugas-tugas mereka. Jika dikaitkan dengan penelitian, maka aplikasi Laut Nusantara adalah sebuah program yang dibuat untuk mempermudah para nelayan untuk mendapatkan informasi seputar lokasi-lokasi tempat ikan berkumpul dan perkiraan cuaca pada saat itu, dan akses pengguna langsung dari genggaman mereka.

Menurut Santoso (2019, p. 7) sebuah aplikasi web progresif memiliki karakteristik sebagai berikut :

1. Progressive. Bekerja disemua user, ganpa melihat web browser yang dipakai, karena telah memiliki peningkatan progresif pada prinsipnya.

2. Responsive. Cocok disegala bentuk device, (desktop, mobile, tablet, lainnya).

3. Connectivity independent. Ditingkatkan dengan service worker untuk bekerja secara offline atau pada jaringan internet kualitas rendah.

4. App-like. Terasa seperti app, karena model App Shell akan memisahkan fungsionalitas aplikasi dari kontennya.

5. Fresh. Selalu up-to-date berkat adanya proses update service worker.
6. Safe. Dilayai melalui HTTPS untuk mencegah pengintaian (snooping) dan memastikan konten tidak rusak.

7. Dicoverable. Teridentifikasi sebagai "Aplication" berkat manifest W3C dan registrasi service worker, sehingga memungkinkan search engine untuk mengenalinya.

8. Re-engageable. Memudahkan keterlibatan user dengan fitur push notification.

9. Installable. Memungkinkan user untuk menambahkan apps yang sering digunakan di layar home screen tanpa harus ke app store.

10. Linkable. Share aplikasi dengan mudah melalui URL, tanpa repot-repot menginstalnya.

Aplikasi yang baik harus memenuhi 10 karakteristik sebuah aplikasi web yang baik sehingga aplikasi yang dibuat tidak cacat atau menjadi sia-sia. Progressive adalah aplikasi dapat digunakan di segala versi OS, Responsive adalah dapat digunakan diberbagai smartphone, selanjutnya Connectivity Independent adalah aplikasi bisa digunakan pada saat jaringan rendah maupun secara offline, App-like merupakan aplikasi mudah dimengerti oleh pengguna, Fresh adalah aplikasi selalu meminta pembaharuan, Safe adalah aplikasi menjamin data penggunanya, yang ketujuh Dicoverable adalah aplikasi dapat ditemukan di google atau browser, Re-engageable adalah aplikasi meminta izin untuk akses lokasi, Installable adalah memungkinkan untuk mengunduh aplikasi lain dalam aplikasi Laut Nusantara, yang terakhir Linkable adalah dapat di share menggunakan link.

\section{Citra}

Menurut Ruslan (2013, p. 75) "Citra merupakan tujuan utama, dan sekaligus merupakan reputasi dan prestasi yang hendak dicapai bagi dunia public relations". Menurut Safitri (dalam Sulandjar \& Nanda, 2020) citra perusahaan adalah persepsi dari suatu 
organisasi yang drekam di memori konsumen dan bekerja sebagai filter yang mempengaruhi persepsi terhadap perusahaan. Citra menunjukkan kesan suatu objek terhadap objek lain yang terbentuk dengan memproses informasi setiap waktu. Citra merupakan tujuan utama yang hendak dicapai oleh perusahaan dengan berdasarkan persepsi yang dipahami oleh masyarakat terhadap jati diri perusahaan dan citra merupakan tujuan utama dan merupakan sebuah prestasi yang hendak dicapai oleh para public relations. Citra yang ingin dicapai humas PT XL Axiata sebagai perusahaan adalah citra yang baik sehingga dapat dipercaya oleh masyarakat khususnya npara nenlayan. Mereka mempunyai program CSR yang sangat banyak dan telah berjalan secara berkala dan terus-menerus sehingga menimbulkan persepsi yang positif dibenak masyarakat bahwa PT XL Axiata sangat berperan aktif dalam membangun bangsa dan berperan aktif dalam kegiatan sosial untuk menyejahterakan masyarakat Indonesia.

Menurut Sutojo (dalam Ardianto dan Soemirat, 2014, p. 65) terdapat lima faktor yang dapat mempengaruhi citra perusahaan:

a. Citra dibangun berdasarkan orientasi manfaat yang dibutuhkan dan diinginkan kelompok sasaran.

b. Manfaat yang ditonjolkan cukup realistis.

c. Citra yang ditonjolkan mudah dimengerti kelompok sasaran.

d. Citra yang ditonjolkan merupakan sarana bukan tujuan untuk usaha.

e. Citra yang ditonjolkan sesuai dengan kemampuan perusahaan.

Jika dikaitkan dengan penelitian, peneliti menyimpulkan bahwa citra perusahaan adalah sebuah kesan yang dimiliki perusahaan melalui kebijakan yang dilakukan oleh humas XL Axiata seperti kegiatan internal maupun eksternal. Dalam hal ini yang ingin dicapai dalam penelitian ini adalah citra perusahaan bagi nelayan. Karena penulis ingin mengetahui bagaimana citra perusahaan XL Axiata dimata publiknya khususnya nelayan melalui program CSR Laut Nusantara. Ada beberapa faktor yang dapat mempengaruhi citra yaitu diantaranya: identitas fisik, identitas non fisik, kualitas hasil dan pelayanan, aktivitas dan pola hubungan, memiliki manfaat yang dibutuhkan kelompok, manfaat yang realistis, citra mudah dimengerti sasaran, citra merupakan sarana bukan tujuan untuk usaha, citra harus sesuai dengan kemampuan perusahaan.

\section{Kerangka Penelitian}

\begin{tabular}{|c|}
\hline PT XL Axiata TBK \\
\hline$\nabla$ \\
\hline Humas XL Axiata \\
\hline$\nabla$ \\
\hline $\begin{aligned} & \text { Aplikasi Mobile Laut Nusantara: } \\
\text { 1. } & \text { Progressive } \\
\text { 2. } & \text { Responsive } \\
\text { 3. } & \text { Connectivity independent } \\
\text { 4. } & \text { App-like } \\
\text { 5. } & \text { Fresh } \\
\text { 6. } & \text { Safe } \\
\text { 7. } & \text { Dicoverable } \\
\text { 8. } & \text { Re-engageable } \\
\text { 9. } & \text { Installable } \\
\text { 10. } & \text { Linkable }\end{aligned}$ \\
\hline$\nabla$ \\
\hline $\begin{array}{l}\text { CITRA PERUSAHAAN } \\
\text { a. Citra dibangun berdasarkan orientasi manfaat yang } \\
\text { dibutuhkan dan } \\
\text { diinginkan kelompok sasaran. } \\
\text { b. Manfaat yang ditonjolkan cukup realistis. } \\
\text { c. Citra yang ditonjolkan mudah dimengerti kelompok } \\
\text { sasaran. } \\
\text { d. Citra yang ditonjolkan merupakan sarana bukan } \\
\text { e. Citra unang ditonjolkan sesuai dengan kemampuan } \\
\text { perusahaan. }\end{array}$ \\
\hline$\downarrow$ \\
\hline Nelayan \\
\hline
\end{tabular}

\section{METODE PENELITIAN}

Menurut Mukhtar (2013, p. 84) "Pendekatan penelitian adalah cara-cara terstruktur, terencana dan terprosedur untuk melklukan sebuah penelitian ilmiah dengan memadukan semua potensi dan sumber yang telah disiapkan".Penelitian ini menggunakan 
paradigma konstruktivisme yang mana konstruktivisme memandang bahwa kenyataan itu hasil konstruksi atau bentukan dari manusia itu sendiri. Kenyataan itu bersifat ganda, dapat dibentuk dan merupakan satu keutuhan. Kenyataan ada sebagai hasil bentukan dari kemampuan berpikir seseorang. Pengetahuan hasil bentukan manusia itu tidak bersifat tetap, tetapi berkembang terus. Penelitian kualitatif berlandasan paradigm konstruktivisme yang berpandangan bahwa, pengetahuan itu bukan hanya merupakan hasil pengalaman terhadap fakta, tetapi juga merupakan hasil konstruksi pemikiran subjek yang diteliti. Pengenalan manusia terhadap realitas sosial berpusat pada subjek dan bukan pada objek, hal ini berarti bahwa ilmu pengetahuan bukan hasil pengalaman semata, tetapi merupakan juga hasil konstruksi oleh pemikiran (Tahir, 2011, p. 57).

Peneliti melakukan pendekatan penelitian dengan terstruktur, terencana dan terprosedur dalam melakukan penelitian tentang tentang Peran Humas XL Axiata melalui aplikasi Mobile Laut Nusantara dalam Meningkatkan Citra Perusahaan bagi Nelayan dengan menentukan jawaban dari rumusan masalah berdasarkan sumber yang telah disiapkan yaitu kepala project Inovasi Sosial XL Axiata dan nelayan. Menurut Yin (2013, p. 109). "Informan-informan kunci sering sekali sangatpenting bagi keberhasilan studi kasus. Mereka tidak hanya memberi keterangantentang sesuatu kepada peneliti, tetapi juga dapat memberi saran tentang sumber-sumber bukti lain yang mendukung." Peneliti menetapkan ibu Siti Siswandari sebagai key informan (1) selaku Head Social Innovation Project dan bapak Tjeptjep Witjahjono selaku Expert m-Fish dan Xmart Village XL Axiata sebagai key informan; (2) karena mengetahui, menguasai informasi atau data untuk menjawab permasalahan penelitian penulis mengenai Peran Humas XL Axiata melalui Aplikasi Mobile Laut Nusantara dalam Meningkatkan Citra Perusahaan bagi Nelayan. Jika dikaitkan dengan masalah pokok penelitian, penulis memilih nelayan untuk dijadikan informan, karena nelayan adalah orang yang memakai langsung aplikasi
Laut Nusantara dan nelayan merupakan target dari aplikasi tersebut.

Menurut Yin (2013, p. 103) terdapat enam pengumpulan data pada studi kasus yaitu: Dokumentasi, Rekaman Arsip, Wawancara, Observasi langsung, Observasi Partisipan, Perangkat Fisik. Jika dikaitkan dengan penelitian, peneliti memakai teknik pengumpulan data melalui wawancara dengan key informan dan informan, serta observasi langsung dan dokumentasi, literature kepustakaan, dokumen arsip dan foto yang berkaitan dengan masalah penelitian akan dioleh dengan melihat persamaan dan perbedaan untuk diambil kesimpulan mengenai Peran Humas XL Axiata melalui Aplikasi Mobile Laut Nusantara dalam Meningkatkan Citra Perusahaan bagi Nelayan.

Menurut Moleong (2012, p. 247) "Proses analisis data dimulai dengan menelaah seluruh data yang tersedia dari berbagai sumber, yaitu dari wawancara, pengamatan yang sudah dilukiskan dalam catatan lapangan, dokumen resmi, gambar, foto dan sebagainya. Setelah dibaca, dipelajari, dan ditelaah, maka langkah berikutnya ialah mengadakan induksi data yang dilakukan dengan jalan membuat abstraksi. Abstraksi merupakan usaha membuat rangkuman yang inti, proses, dan pernyataan-pernyataan yang perlu dijaga sehingga tetap berada di dalamnya. Langkah selanjutnya adalah menyusunnya dalam satuan-satuan. Satuan-satuan itu kemudian dikategorikan dalam langkah berikutnya kategori-kategori itu dilakukan sambil membuat koding. Tahap akhir dari analisis data ini adalah mengadakan pemeriksaan absahan data dalam mengolah hasil sementara menjadi teori substansif dengan menggunakan beberapa metode tertentu".

\section{HASIL DAN PEMBAHASAN}

Hasil wawancara yang peneliti peroleh berasal dari wawancara bersama key informan 1 yakni ibu Siti Siswandari, selaku Head of Social Innovation Project PT XL Axiata dan 
key informan 2 yakni bapak TjeptjepWitjahjono selaku Expert m-Fish dan Xmart Village, yang merupakan orang yang paling mengetahui, memahami, ikut serta dalam perencanaan dan kegiatan CSR Aplikasi Laut Nusantara. Sementara itu, para informan dalam penelitian ini adalah para nelayan yang berada di cilincing Jakarta Utara

Berikut adalah identitas dari key informan dan para informan:

- Key Informan 1

Nama : Siti Siswandari

Usia : $\quad$ :57 Tahun

Pekerjaan : Head of Social Innovation Project

- Key Informan 2

Nama : TjeptjepWitjahjono

Usia : 48 Tahun

Pekerjaan : Expert m-Fish dan Xmart Village

- Informan 1

Nama : Jumani

Usia : 49 Tahun

Pekerjaan : Nelayan

- Informan 2

Nama : Syarifudin

Usia : 30 tahun

Pekerjaan : Nelayan

- Informan 3

Nama : Ambo Ako

Usia : 37 tahun

Pekerjaan : Nelayan

- Informan 4

Nama : Supriyadi

Usia : 40 tahun

Pekerjaan : Nelayan

- Informan 5

Nama : Nartiman

Usia : 42 tahun

Pekerjaan : Nelayan

\section{Aplikasi Laut Nusantara}

\section{A. Progressive}

Menurut Siti dan Tjetjep (2019), aplikasi ini hanya bisa digunakan di android belum bisa di OS iOS atau iphone dan hanya bisa digunakan di atas kitkat dibawah itu mungkin tidak bisa. Selanjutnya seluruh informan aplikasi ini bisa digunakan diseluruh versi OS karena masinmasing dari kita berbeda-beda versi OS nya. Hasil observasi penulis di lapangan bahwa benar Aplikasi Laut Nusantara dapat digunakan diseluruh versi OS yang berbasis android. Seluruh infroman atau responden bisa digunakan di berbagai sistem OS dan sistem OS yang mereka pakai beragam ada yang oreo, lollipop serta mereka merasakan kelancaran pada saat memakai aplikasi tersebut.

Hasil observasi apliakasi tersebut dapat dioperasikan diberbagai Operating System berbasis android. Banyak para nelayan yang mempunya berbagai macaam handphone yang dalam hal ini beragam versi OS nya tetapi aplikasi Laut Nusantara tetap dapat dioperasikan secara normal.

\section{B. Responsive}

Menurut Siti dan Tjetjep (2019), mengatakan aplikasi Laut Nusantara dapat dijalankan atau digunakan disemua tipe HP atau semua merek HP tetapi untuk Apple belum bisa karenakita tahu target kitra nelayan, yang paling banyak menggunakan android. Hasil observasi penulis, bahwa para nelayan yang hadir semuanya menggunakan android tidak ada yang memakan brand Apple sehingga humas XL sudah mengetaui betul apa yang diinginakan para nelayan. Infroman aplikasi tersebut dapat digunakan diberbagai smartphone dan merek smartphone yang digunakan oleh nelayan tersebut beragam dan mereka bisa menjalankan aplikasi tersebut. Ako (2019), mengatakan bisa juga karena teman-teman saya sudah banyak yang pakai dan itu berbagai macam HP, yang saya pake sendiri ya merek huwawei.

Aplikasi Laut Nusantara baru dapat dioperasikan di smartphone berbasis android artinya belum bisa dipakai diaphone. Ini sejalan dengan kenyataan di lapangan yang mayoritas nelayan hanya memakai smartphone berbasis android hanya sedikit yang menggunakan iphone. 


\section{Connectivity Independent}

Menurut Siti dan Tjetjep (2019), aplikasi dapat dijalankan secara offline dengan catatan pengguna sudah mengunjungi aplikasi tersebut dan sudah memakainya pada saat masih online artinya aplikasi tersebut dapat dijalankan dengan menggunakan GPS yang telah dicoba pada saat online. Ambo Ako, et. al, (2019) aplikasi tersebut tidak bisa digunakan pada saat offline. Jumani (2019), mengatakan bisa dijalankan pada saat offline. Menurut penulis yang melakukan observasi aplikasi Laut Nusantara bisa dijalankan dalam kondisi offline dengan catatan pada saat online pengguna telah mengunjungi aplikasi tersebut.

Dalam Connectivity independent aplikasi bisa dijalankan saat offline namun dengan catatan pengguna telah mengunjungi aplikasi tersebut pada saat online ini berkaitan dengan GPS yang ada dihp para pengguna, jadi nantinya pada saat offline GPS tetap berjalan walaupun kondisi hp tidak ada sinyal ataupun offline.

\section{App Like}

Menurut Siti dan Tjetjep (2019), bahwa secara aplikasi memang canggih tetapi memang kita mendesainnya user friendly yang diamana agar para nelayan dapat langsung mengerti aplikasi tersebut. Supriyadi, et. al, (2019) aplikasi tersebut memang sangat mudah dimengerti sehingga kami tidak perlu belajar yang memakan waktu. Lalu penulis melakukan observasi, hasilnya aplikasi tersebut memang mudah dijlankan oleh siapapun terutama para nelayan sehingga pada saat nelayan diberikan pengarahan atau pengajaran tentang aplikasi tersebut mereka langsung mengerti bagaimana cara mengoperasikannya. Seluruh informan aplikasi sangat mudah digunakan dan kami langsung mengerti ketika disosialisasikan dan langsung dapat mengerti ketika kami memakai aplikasi tersebut.

Aplikasi ini sangat mudah dipahami kontennya meskipun terbilang canggih namun aplikasi ini isinya sangat sederhana sehingga para nelayan yang menerima bantuan tersebut dapat langsung menggunakan aplikasi tersebut.

\section{E. Fresh}

Menurut Siti dan Tjetjep (2019), aplikasi Laut Nusantara sudah melakukan 3 kali develop terhitung sejak dilaunching Agustus 2018 dan aplikasi tersebut pun baru saja dilakukan pembaharuan. Lalu Nartiman, et. al, (2019) memang ada pembaharuan pada saat awal kita memakainya itu sebanyak dua kali, Jumani (2019), mengatakan tidak mengatahui hal tersebut. Menurut penulis yang melakukan observasi yang hasilnya, memang benar aplikasi tersebut sering meminta pembaharuan untuk menigkatkan kualitas isi dari palikasi tersebut terbukti tanggal 23 Juni 2019 aplikasi tersebut meminta pembaharuan.

Dalam hal Fresh aplikasi ini selalu dilakukan develop atau pembaharuan guna meningkatkan kualitas dari aplikasi tersebut maupun untuk memperbaharui isi dari aplikasi tersebut. Humas XL juga selalu memperbaiki atau mendevelope aplikasi supaya aplikasi tersebut uptodate.

\section{F. Safe}

Menurut Siti (2019), aplikasi pasti aman karena PT XL Axiata juga sudah biasa mengurus atau berkecimpung di Big Data. Syarifudin, et. al, (2019) insya aman dan kami sangat yakin aman. Hasil observasi penulis adalah temuan di lapangan memang aplikasi tersebut menjamin keamanan data pengguna itu terlihat dari pertama kali kita memakai aplikasi tersebut akan muncul pemberitahuan tentang aplikasi tersebut dan kemanan data pengguna. Seluruh informan kami yakin aman dan insya allah aman karena yakin dengan perusahaan besar seperti XL Axiata.

Kemanan data pengguna didalam aplikasi Laut Nusantara terbilang aman karena sebelum pengguna baru menggunakan 
aplikasi tersebut pengguna diminta untuk mengisi nama, nomor telepon dan mensetujui ketentuan-ketentuan dari aplikasi Laut Nusantara.

\section{G. Discoverable}

Menurut Siti dan Tjetjep (2019), bisa sangat mudah bahkan ketika kita cari di google itu akan keluar foto-foto pada saat bu susi menteri KKP pada saat melaunching aplikasi tersebut. Jumani, et. al, (2019) iya sangat mudah pak ketika kami cari di google maupun browser, kita mencari karena ingin megetahui tentang aplikasi tersebut. Lalu penulis melakukan observasi yang hasilnya, benar memang mudah ditemukan disegala search engine ketika kita mengetik Laut Nusantara dan ketika kita mencarinya itu keluar semua tentang aplikasi tersebut dan berita-berita tentang aplikasi Laut Nusantara. Seluruh informan sangat mudah ketika kami searching di google itu langsung keluar, kami searching ingin tau Aplikasi Laut Nusantara itu apasi dan ternyata sangat mudah mencarinya. Aplikasi ini sangat mudah ditemukan disegala search engine dalam hal ini google atau pun browser. Didalam search engine tersebut dapat ditemukan tentang apa itu aplikasi Laut Nusantara, gambar-gambar serta berita portal tentang aplikasi tersebut.

\section{H. Re-enggagement}

Menurut Siti dan Tjetjep (2019), iya itu sudah pasti karena kaitannya dengan data pengguna dan pasti ditanyakan karena allow atau tidak hp tersebut untuk mengakses lokasi, audio maupun kontak. Syarifudin, et. al, (2019) iya diminta untuk membuka akses dan kami izinkan sedangkan Nartiman (2019), tidak tahu. Selanjutnya penulis melakukan observasi yang hasilnya, benar ketika kita menjadi pengguna baru aplikasi tersebut meminta untuk membuka atau meminta izin untuk mengakses lokasi, audio maupun kontak dari hp pengguna.

Dalam Re-engageable pada saat pengguna baru yang ingin memakai aplikasi
Laut Nusantara, aplikasi ini meminta akses lokasi, audio dan kontak untuk kemudahan pengguna pada saat menggunakan aplikasi tersebut.

\section{Installable}

Menurut Siti dan Tjetjep (2019), tidak bisa di aplikassi Laut Nusantara hanya khusus Laut Nusantara saja. Dan seluruh informan mengatakan tidak bisa dan tidak pernah meminta untuk mengunduh aplikasi lain. Hasil observasi penulis di lapangan memang tidak bisa mengunduh aplikasi lain didalam aplikasi Laut Nusantara atau membuka aplikasi lain didalam Laut Nusantara. Seluruh informan bahwa tidak bisa bahwa pernah meminta mengunduh aplikasi lain.

Aplikasi Laut Nusantara tidak dapat mengunduh aplikasi lain selainaplikasi Laut Nusantara dan aplikasi ini juga tidak dapat membuka aplikasi laindidalam Laut Nusantara karena aplikasi ini merupakan aplikasi CSR bukanaplikasi yang mempunyai iklan.

\section{J. Linkable}

Menurut Siti dan Tjetjep (2019), aplikasi laut nusantara bisa dibagikan melalui URL atau link tetapi lebih baik langsung saja mencari di play store Laut Nusantara itu lebih mudah. Nartiman, et. al, (2019) bisa da mereka sudah mencoba membagikan itu ke teman-teman mereka. Hasil observasi penulis memang benar mudah sekali membagikan aplikasi tersebut dengan URL atau link dan ketika link itu dibagikan penerima link tersebut dapat langsung mengunduhnya dengan masuk kedalam playstore. Seluruh informan bahwa aplikasi tersebut dapat dishare kepada temannya dan kami sudah mencobanya. Kami melakukan itu untuk memberi informasi kepada teman-temannya bahwa ada aplikassi yang dapat

digunakan pada saat melaut. Dalam Linkable aplikasi Laut Nusantara dapat dibagikan dengan link yang dapat dishare kepengguna 
lainnya sehingga pengguna lain dapat mengetahui aplikasi tersebut dan bisa mengunduh aplikasinya.

\section{Citra}

\section{Citra dibangun berdasarkan orientasi manfaat yang dibutuhkan dan diinginkan kelompok sasaran}

Menurut Siti (2019), manfaatnya baik, nelayannya sendiri mereka senang karena mereka bisa mendapatkan ikan tanpa harus minta siapa-siapa. Tjetjep (2019), aplikasi Laut Nusantara dibuat berdasarkan orientasi atas kebutuhan nelayan itu sendiri. Adapun menurut seluruh informan menyatakan bahwa mereka sangat merasakan manfaat dari aplikassi tersebut dan aplikasi itu juga sangat kami butuhkan untuk melihat sebaran ikan di laut lepas.

Kegiatan CSR Aplikasi Laut Nusantara ini memberikan manfaat yang diinginkan serta dibutuhkan oleh para nelayan yang hadir, karena nelayan akan mendapatkan aplikasi yang dapat membantu mereka dalam melaut, pastinya akan sangat berguna dan kegiatan ini juga merupakan manfaat yang dibutuhkan dan diinginkan oleh para nelayan sehingga memberikan citra yang positif bagi XL Axiata.

\section{Manfaat yang ditonjolkan cukup realistis}

Menurut Siti (2019), sudah sangat jelas manfaat yang realistis dan memang langsung dirasakan para nelayan. Dijelaskan ada seratus handphone yang datang bisa sampe 200-300 orang. Tjetjep (2019) sangat realistis karena berdasarkan orientasi dan manfaat yang sudah kita survey sebelumnya. Menurut informan bahwa manfaatnya dapat langsung dirasakan jadi tidak takut lagi untuk melaut, dan bisa menjadi tahu berapa bahan bakar yang dibutuhkan untuk melaut serta melaut dengan aplikasi Laut Nunsatara sedikit menambah penghasilan mereka.
Manfaat yang diberikan dari kegiatan CSR Aplikasi Laut Nusantara ini sangat realistis dan dapat langsung dirasakan, karena memang memberikan sesuatu yang dibutuhkan oleh para nelayan berupa Aplikasi Laut Nusantara yang dapat membantu mereka dalam mencari ikan sehingga XL Axiata mendapatkan citra yang baik bagi nelayan.

\section{Citra yang ditonjolkan mudah dimengerti kelompok sasaran}

$\mathrm{Bu}$ Siti (2019), menyatakan rasa senang bahwa sampai dipanggil Koominfo, bahkan kementerian pertanian juga minta dibuatkan aplikasi petani, Bu Siti (2019) merupakan bentuk citra perusahaan. Pak Tjetjep menyatakan bahwa citra yang ditonjolkan mudah dimengerti. Begitu juga Seluruh informan menyatakan bahwa, kegiatan Laut Nusantara itu merupakan sebuah citra yang ditunjukkan oleh PT XL Axiata kepada nelayan dan XL selalu tepat kalo membuat program untuk nelayan.

PT XL Axiata Tbk sebagai perusahaan yang peduli dan sangat memperhatiakan masyarakat serta paham akan tujuan atau program pemerintah sehingga masyarakat mudah memahami terutama para nelayan yang hadir dalam kegiatan CSR Aplikasi Laut Nusantara tujuannya adalah XL ingin membangun citra yang positif bagi perusahaannya.

\section{Citra yang ditonjolkan merupakan sarana bukan tujuan untuk usaha}

Menurut Siti (2019), citra yang ditonjolkan merupakan sarana bukan tujuan usaha karena salah satu program Xl yaitu memajukan bangsa, XL memajukan Indonesia. Tjetjep (2019), aplikasi Laut Nusantara adalah salah satu kegiatan CSR XL Axiata. Menurut informan, akan bagus kalau XL memakai kegiatan CSR Aplikasi Laut Nusantara sebagai sarana mereka untuk meningkatkan citra mereka. Syarifudin (2019) 
menyatakan kalau sarananya sangat bagus dan nelayannya bisa menilai bagusnya atau tidaknya aplikasi tersebut.

Citra yang ditonjolkan oleh PT XL Axiata dalam hal ini humas XL Axiata sebagai perusahaan yang peduli kepada masyarakat dan mendukung program pemerintah melalui kegiatan CSR Aplikasi Laut Nusantara ini adalah sarana untuk mewujudkan hal tersebut. Meskipun mendapatkan citra yang positif merupakan tujuan utama mereka tetapi PT XL Axiata tidak membesar-besarkan diri mereka, mereka tetap menjalankan kegiatan tersebut sesuai dengan jalannya kegiatan tersebut.

\section{Citra yang ditonjolkan sesuai dengan kemampuan perusahaan}

Menurut Siti (2019), citra yang ditonjolkan sesuai dengan kemampuan perusahaan, hal tersebut pernah dibuktikaan saat media gathering di Banyuangi satu kegiatannya adalah Laut Nusantara, dimana wartawan seluruh Indonesia benar-benar melihat cara beroperasinya aplikasi tersebut. Tjetjep (2019) dan seluruh informan menyatakan bahwa, XL adalah perusahaan yang besar dan CSR adalah salah satu produk solusi dari XL jadi sangat mampu kalau cuma meluncurkan aplikasi

Dari hasil penelitian, citra yang ditunjukkan PT XL Axiata Tbk sebagai perusahaan yang memperhatikan masyarakat sudah sesuai dengan kemampuan perusahaan yang juga menyesuaikan dengan kebutuhan para nelayan jukung atau nelayan kecil, lalu kemampuan ini juga dapat dilihat dari peluncuran aplikasi pertama unutk nelayan yaitu M-Fish yang selanjutnya diganti menjadi nelpin. Karena nelpin tidak bisa didevelop sedangkan humas XL membutuhkan aplikasi yang bisa didevelop maka lahirlah aplikasi Laut Nusantara ini yang bekerjasama dengan Kementerian Kelautan dan Perikanan dalam hal ini Badan Riset dan Observasi Laut (BROL).

\section{PENUTUP}

\section{Simpulan}

Berdasarkan hasil penelitian terhadap Peran Humas XL Axiata melalui Aplikasi Mobile Laut Nusantara dalam Meningkatkan Citra Perusahaan Bagi Nelayan, dapat disimpulkan bahwa penyelenggaraan kegiatan Corporate Social Responsibility yang dilaksanakan oleh Humas PT XL Axiata telah berjalan dengan baik mereka telah membuat kegiatan yang membuat para nelayan merasa terbantu oleh layanan dari Aplikasi Laut Nusantara tersebut.

Dari aplikasi yang sudah sangat baik tersebut citra positif untuk perusahaan sudah pasti didapatkan oleh PT XL Axiata itu terlihat dari wajah dan observasi penulis di lapangan.

\section{Saran}

1. Pada bagian Progressive Aplikasi Laut nusantara hanya bisa digunakan di android versi kitkat ke atas belum bisa di iOS atau iphone, sebaiknya aplikasi Laut Nusantara juga bisa digunakan di versi iOS atau iphone meskipun nelayan jarang yang menggunakan iphone tetapi hal ini dinilai sangat penting karena para nelayan tidak hanya menggunakan android.

2. Kegiatan Aplikasi Laut Nusantara sudah berjalan baik, terus tingkatkan inovasi dari aplikasi Laut Nusantara agar aplikasi tersebut semakin canggih, sehingga lebih mempermudah para pengguna khususnya nelayan.

\section{DAFTAR PUSTAKA}

Alvin, S. (2020). Strategi Komunikasi Politik Juru Bicara Wakil Presiden 2014-2019 sebagai Humas Pemerintah. Jurnal Komunikasi. https://doi.org/10.21107/ilkom.v14i1. 6031 
Ardianto, E., \& Soemirat, S. (2014). Handbook of Public Relations (Pengantar Komprehensif). Bandung: Remaja Rosdakarya.

Awza, R., Salam, N., E.,Nurjanah. (2013). Pengelolaan Corporate Social Responsibility (CSR Dalam Membangun Citra Perusahaan. Jurnal Komunikasi. https://fisip.unri.ac.id/wpcontent/uploads/2021/01/Artikel_PE NGELOLAAN-CORPORATESOCIAL-RESPONSIBILITY-CSRDALAM-MEMBANGUN-CITRAPERUSAHAAN.pdf

Embracing Digitization For Our Future. (2018). Retrieved from https://upperline.id/uploads/annual_re ports/file/file_annual_5e12f3aaac5d3. pdf

Gassing, S. S., \& Suryanto. (2016). Public Relations. Yogyakarta: Andi Yogyakarta.

Hutami., N. Irwansyah. (2019). Pemanfaatan Aplikasi Mobile Kitabisa Dalam Pelaksanaan Crowdfunding Di Indonesia. Komunikasi. https://journal.trunojoyo.ac.id/komuni kasi/article/view/5357/4251

Khadijah., S. (2019). Strategi Publik Relations Dalam Membangun Citra Perusahaan (Studi Deskriptif Membangun Hubungan Baik Dengan Media Dalam Upaya Meningkatkan Citra Perusahaan). Jurnal Kajian Komunikasi, Bahasa dan Budaya. http://jurnal.unismabekasi.ac.id/index. $\mathrm{php} / \mathrm{makna} /$ article/view/770

Kriyantono, R. (2010). Teknik Praktis Riset Komunikasi: Disertai Contoh Praktis Riset Media, Public Relations, Advertising, Komunikasi Organisasi, Komunikasi Pemasaran. Jakarta: PT Kencana Prenada Media Group.
Kriyantono, R. (2012). Menerapkan Praktik Public Relations di Indonesia dengan Teori dan Riset. Jakarta: Kencana Prenada Media Group.

Moleong, L. (2012). Metodologi Penelitian Kualitatif. Bandung: PT. Remaja Rosdakarya.

Mukhtar. (2013). Metodelogi Penelitian Kualitatif: Paradigma Baru Ilmu Komunikasi dan Ilmu Sosial Lainnya. Bandung: PT Remaja Rosdakarya.

Prastowo, J., \& Huda, M. (2011). Corporate Social Responsibility (Kunci Meraih Kemuliaan Bisnis). Jakarta: Suhana Bhara.

Pratomo, Y. (2018). Kominfo Keluarkan Aturan 1 NIK Bisa Daftar Banyak Nomor Kartu Seluler. Retrieved from https://tekno.kompas.com/read/2018/ 05/08/12424817/kominfo-keluarkanaturan-1-nik-bisa-daftar-banyaknomor-kartu-seluler

RM, A. S., \& Moertijoso, R. B. (2015). Strategi Media Relations Humas PT.Pelabuhan Indonesia III Dalam Handling Crisis Pemberitaan Media. Jurnal Komunikasi. Retrieved from https://journal.trunojoyo.ac.id/komuni kasi/article/view/1152/975

Ruliana, P., Lestari, P., \& Andrini, S. (2019). Model Komunikasi Korporat Sari Ater Hotel \& Resort Dalam Menghadapi Revolusi Industri 4.0. Jurnal ASPIKOM, 4(1), 60-82. Retrieved from http://jurnalaspikom.org/index.php/as pikom/article/view/535/192

Ruslan, R. (2013). Metode Penelitian Public Relations dan Komunikasi. Bandung: Rajawali Pers.

Santoso, H. (2019). Membangun Aplikasi Mobile dengan Progressive Web App (PWA). Yogyakarta: CV Lokomedia. 
Sugiyono. (2016). Metode Penelitian Kuantitatif, Kualitatif dan Kombinasi (MIX METHODS). Bandung: Alfabeta.

Sulandjar, R., \& Nanda, A. (2020). Strategi Public Relations Dalam Membangun Citra Perusahaan Pada PT TIKI JNE. Jurnal Egaliter, 4(6), 15-26. Retrieved from http://jurnal.unpand.ac.id/index.php/e gr/article/viewFile/1548/1507
Tahir. (2011). Metodologi \& Teori Hubungan Internasional. Jakarta: Refika Aditama.

Turban, E. (2012). Electronic Commerce 2012 (P. Grasindo, Ed.). Jakarta.

Yin, R. K. (2013). Studi Kasus Desain dan Metode (M. Djauzi Mudzakir, Penerjemah). Jakarta: Raja Grafindo Persada. 
16 | Jurnal Komunikasi, Vol. 15 No. 01, Maret 2021: 1-16 